日臨外会誌 77 (11)，2697-2700，2016

症例

繰り返す気胸を契機に発見されたBirt-Hogg-Dube症候群の 1 例

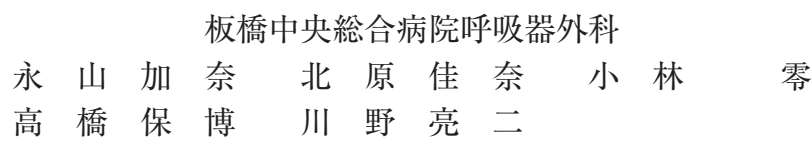

症例は35歳, 女性. 6 年前に左自然気胸の診断にて他院で手術を施行され，その後 2 回再発を認めたが保存的治療で軽快した，今回, 起床時より右胸痛を自覚したため近医 を受診し，II度の右気胸と診断され当科紹介となった，胸部CTでは右中下葉に多発す る肺囊胞を認め, 母親に気胸の既往があったことから, 遺伝性肺囊胞性疾患が疑われた. 異時性両側気胸であることから手術適応と判断し, 胸腔鏡下肺囊胞切除術を施行した. 術後経過は良好であり，第 5 病日に退院となった。退院後に施行した遺伝子検査にて FLCN 遺伝子のexon12において挿入変異を認め, BHD 症候群の所見に一致した. BHD 症候群は稀な疾患であり，その表現型が様々であることや，確定診断に遺伝子検査が必 須であることから診断が難しいとされる．今回，繰り返す気胸を契機に診断された BHD 症候群の 1 例を経験したので報告する。

索引用語：BHD症候群, 気胸, 肺囊胞

\section{はじめに}

Birt-Hogg-Dube症候群（以下BHD症候群）は稀 な疾患で，表現型が様々であることや，遺伝子検査が 必要なことから確定診断に至るのが難しいとされる.

われわれは繰り返す気胸歴をもつ患者が，家族歴. 身体所見・遺伝子検査によって最終的にBHD症候群 の診断に至った 1 手術例を経験したので報告する.

症例

症例 : 38歳, 女性.

主訴：右胸痛

既往歴 : 左気胸に対し胸腔ドレナージを行い，以後 2 回再発し同様の手技を受けた。

家族歴：母親が気胸で胸腔ドレナージを受けたこと があり，顔面には白色の小丘疹が多発していた。

喫煙歴：なし。

現病歴：平成 26 年 5 月起床時より右胸痛を自覚し, 前医を受診した。胸部X線検查にてII度の右気胸を認 め, 加療目的に当科紹介となった。

現症：身長169cm，体重58kg. 血圧 $127 / 60 \mathrm{mmHg}$,

2016年 6 月 2 日受付 2016 年 8 月 20 日採用

〈所属施設住所〉

干174-8691 東京都板橋区小豆沢 $2-12-7$
脈拍 $84 / \mathrm{min}$. 母親の顔面には黄白色の小丘疹が多発 していたが，本人には認められなかった（Fig. 1).

血液検査所見 : 末梢血液検査, 生化学検査に異常を 認めなかった。

初診時胸部単純 $\mathrm{X}$ 線所見：II度の右気胸を認めた (Fig. 2).

胸部 CT 所見 : 右中下葉・左下葉を中心に囊胞が多 発しており，特に縦隔側・肺底部に約 $4 \mathrm{~cm}$ 大の比較 的大きい囊胞を認めた (Fig. 3)。囊胞の数は 6 年前 に施行された胸部 CTと比較して，増加していた。

以上より，両側異時性気胸であることから手術適応 と判断し, 胸腔鏡下肺囊胞切除術を施行した.

手術所見（Fig. 4）：右S5 縦隔側に約 $4 \mathrm{~cm}$ の比較 的大きな囊胞を認め，ステイプラーを用いて部分切除 した。 その他肉眼的に可視できる囊胞を上葉の葉間面 に 3 箇所, 中葉に 2 箇所, 下葉に 3 箇所認めたため, 結紮処理した。ステイプラー断端と結紮した部分を被 覆するように，中下葉全体に酸化セルロースメッシュ を貼付した。手術時間は 2 時間11分，出血は少量であ った。

病理標本 : 通常の bulla やbleb の組織像とは異なり, 囊胞壁の内腔面は 1 層の肺胞上皮に被覆され，壁内に は弾性線維の増生を伴っていた（Fig. 5)。家族歴を 


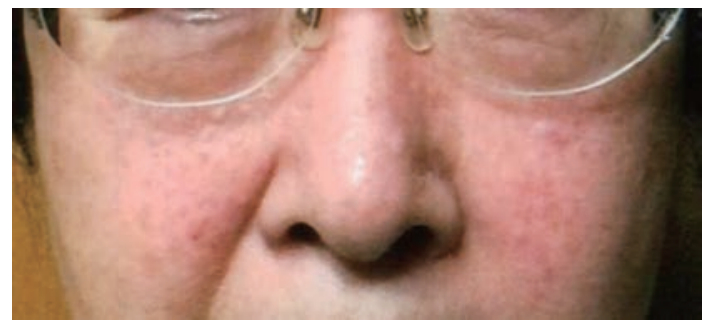

Fig. 1 母親の顔写真 : 顔面に黄白色の小丘疹が多発し ているのを認めた.

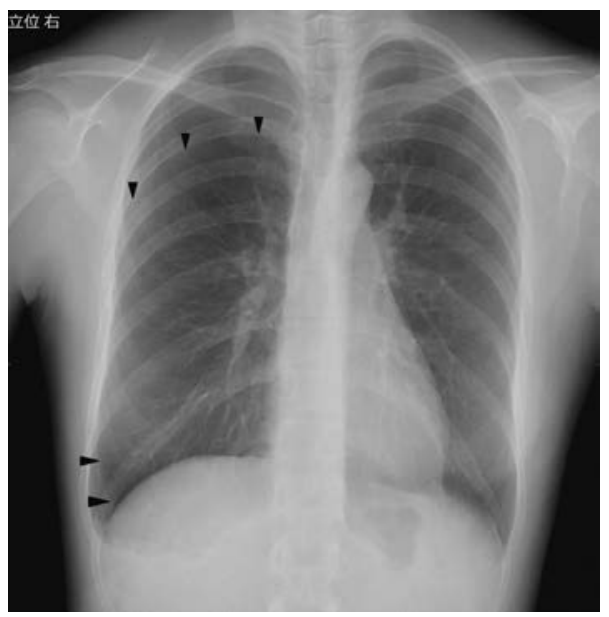

Fig. 2 初診時胸部単純 $\mathrm{X}$ 線写真 : 右気胸を認め た.

もつ, 妊娠可能な年齢の女性に発生した多発性肺囊胞 であり, リンパ脈管筋腫症（LAM）などの遺伝性囊 胞性肺疾患を疑ったが， $\alpha$ 平滑筋アクチン, $\mathrm{HMB}-45$ 陽性の平滑筋細胞の増生所見はなく, LAMは否定的 であった。

術後経過：術後経過は良好で, 術後 2 日目にドレー ンを抜去し, 術後 5 日目に退院した。

以上の臨床的特徵から遺伝性囊胞性肺疾患を疑い,

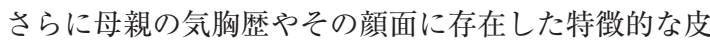
疹から，BHD症候群を疑った。患者の血液検体での 遺伝子検查ではFLCN 遺伝子のexon12の挿入変異を 認め，BHD症候群と確定診断することができた（Fig. 6).

術後 12 力月間外来にて経過観察しているが，気胸の 再発や全身の異常は認めていない.

\section{考察}

BHD症候群は1977年にカナダの皮膚科医Birt，病

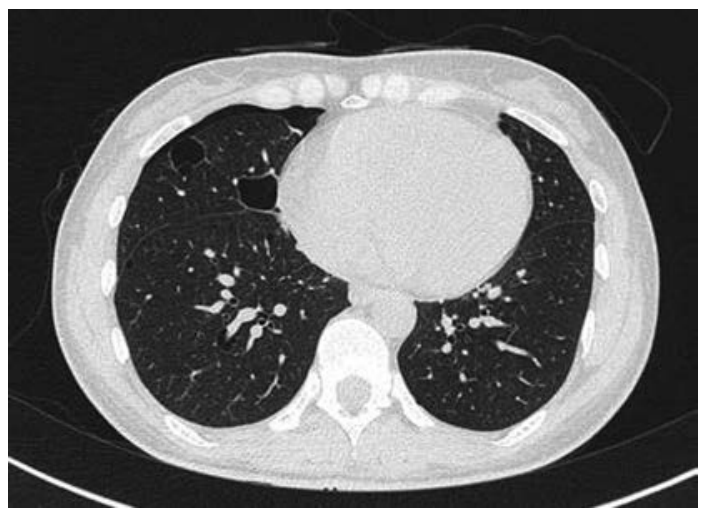

Fig. 3 胸部 CT : 胸腔ドレナージ後に撮影した. 特に縦 隔側・肺底部に比較的大きい肺囊胞を認めた.

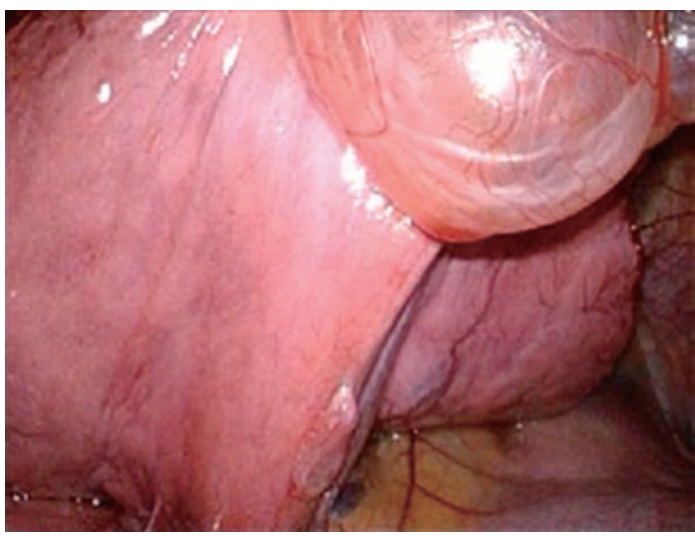

Fig. 4 手術所見：右中下葉を中心に大小の多発する bullaを認めた

理医 Hogg, 内科医Dube らによって報告された，家 族性に皮膚病変を認める常染色体優性遺伝疾患であ る1)。その皮膚病変のほとんどは頭頸部に好発する主 に線維毛包腫と呼ばれる良性腫瘍である2).

2002年Zbarらは33家系223人の大規模な検討を行 い，CT上肺囊胞を全症例の $83 \%$ に扔いて認め，皮膚 病変以外の合併疾患の中では最も多いことを確認し だ)．以後，症例の集積がなされるにつれ，合併する 病変の頻度が徐々に明らかになり, 線維毛包腫, 肺病 変 (肺囊胞・自然気胸), 腎腫瘍がBHD症候群の 3 主 徵と考えられるようになった。本症例では多発肺囊胞 や気胸といった肺病変のみであったが，気胸の家族歴 があることや線維毛包腫と思われる特徴的な皮疹が母 親の顔面にあるのを認めたため，BHD症候群が鑑別 疾患としてあがった 


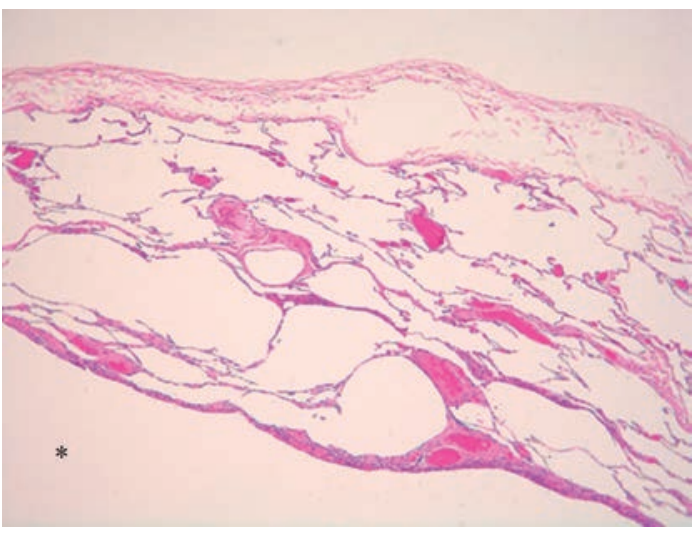

Fig. 5 病理標本 : 囊胞（*) 壁の内腔面は 1 層の肺胞 上皮に被覆されていた（H.E.染色）。

2007年 Toro らは89家系198人における比較的大規模 な検討を行い, BHD症候群の肺病変について, 肺囊 胞の数が多いほど, また肺囊胞の総容積が大きいほど 気胸の発症率が高いことを示した。この報告ではさら に, 右下葉肺実質内の囊胞数, 右中葉の胸膜に接した 囊胞数などもそのリスク因子として挙げており興味深 (い). BHD症候群における肺囊胞の局在部位は特徵的 であり, 通常の bullaやblebは肺尖部に多いのに対し, 下葉・縦隔側・胸膜直下に多い傾向がある ${ }^{5)}$. 本症例 でも右中下葉の縦隔側に比較的大きな囊胞が多数認め られ, BHD症候群の特徴に一致した。

2005年Schmidt らは，53家系219人に扔ける大規模 な検討を行い，3 主徵全てをもつ症例は41.5\%, 肺病 変と皮膚病変をもつ症例は $41.5 \%$, 肺病変と腎病変は $2 \%$ あ゙あり, BHD 症候群には様々な表現型があるこ とがわかった ${ }^{6)}$. したがって, BHD症候群に伴う気胸 であっても,他病変の存在を注意深く検索しなければ, 日常遭遇する自然気胸と診断されている症例が少なか らず存在している可能性がある。実際に, 国内の BHD 患者や医療従事者に対して情報提供を行ってい る『BHD ネット』のホームページでは, 自然気胸の $10 \%$ 程度にBHD 症候群による気胸が含まれていると 述べられている.

BHD症候群に発生する腎腫瘍は1999年に初めて報 告され7)，BHD患者の約 $20 \% に$, 多くは両側性・多発 性に発生し, 組織型も多彩である。本邦では比較的悪 性度の低い嫌色素性細胞癌や嫌色素性細胞癌とオンコ サイトーマのハイブリッドが約 $80 \%$ と大部分を占めて いるが, 乳頭状細胞癌や淡明細胞癌も一部みられ, 腎

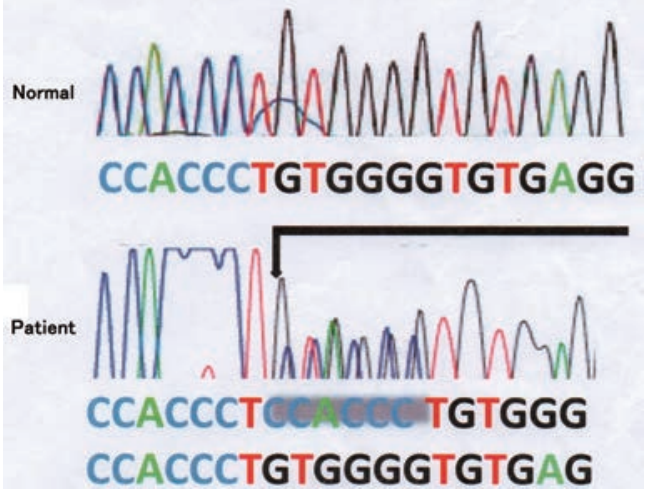

Fig. 6 遺伝子解析結果 : FLCN 遺伝子exon12にお いて, nt.1851-1857のシークエンス部位にヘテロ接 合性に 7 塩基挿入を認めた.

癌死は発症例の $13 \%$ と報告されており ${ }^{8)}$, BHD 症候群 に㧍ける腎腫瘍は重要な生命予後因子となる。

BHD ネットを組織した Furuyaらは，アジアに120 家系（本邦は110家系）のBHD患者が存在しているこ とを把握し，315名中 230 名に気胸歴があり，61名に腎 癌を認めた。皮膚病変から診断に至ることが多い欧米 とは異なり，アジアにおいては気胸がきっかけで診断 に至ることが多いとしている. BHD 症候群に伴う肺 病変は呼吸機能も正常であることが多いが，腎腫瘍を 合併した場合はそれが予後規定因子となりうる。 FLCN 遺伝子の exon9 変異例では腎腫瘍の合併が多い という報告もあり ${ }^{4)}, \mathrm{BHD}$ 症候群を疑う症例では, 遺 伝子検査を行って正確に診断し, genotypeを把握し ておくことも腎腫瘍をスクリーニングする一つの手段 となりうる,

腎腫瘍の発症年齢は40歳以降に多いとされ ${ }^{33}$ ，本疾 患における気胸の好発年齢 $(20-30 \text { 歳台 })^{5)}$ と時間的な 隔たりがある、気胸を契機にBHD症候群の確定診断 が得られることで, 生命予後を左右させる腎腫瘍の早 期発見につながる可能性があり, 気胸の治療後もエコ 一やCT・MRIでの腎病変の検索や厳重な経過観察が 必要である. 2012年に米国で開催された第 4 回BHD シンポジウムでは, 米国国立がん研究所のグループよ り, 遺伝子検査で確定診断されたBHD患者の腎病変 に対する検診として, CT/MRIを 2 年に 1 回施行し, $5 \mathrm{~mm}$ 以上の腎囊胞が見つかった場合は 1 年に 1 回施 行するが，腎腫瘍の家族歴があればより慎重な定期検 診を推奨するという提言があった。しかし，欧米と日 本では画像診断の利用頻度も異なっており，国内にお 
ける診療ガイドラインの早期整備が望まれる，本症例 では現在 1 年に 1 回のCTを施行しており, 腎病変の 合併は認めていない，また，皮痛病変と肺病変をもつ 母親自身に遺伝子検査は行っていないが, 娘の確定診 断を受け事実上BHD 症候群として他院で精査され, 経過観察されている.

\section{結語}

気胸は呼吸器外科領域において日常的に遭遇する疾 患ではあるが，稀にBHD症候群に伴って起こる場合 がある.われわれは身体所見や画像所見，家族歴の聴 取など，まずは基本的な診察を通して BHD症候群を 鑑別診断としてあげなければならない.そして，その 疑いがある場合には生命予後因子となる腎病変の精査 が必要であり，他科とも連携した長期的な経過観察が 重要と考える.

\section{謝 辞}

稿を終えるにあたり，遺伝子解析にご協力いただき ました横浜市立大学医学部分子病理学講座の古屋充子 先生に深く感謝いたします.

利益相反：なし

\section{文献}

1) Birt AR, Hogg GR, Dube J : Hereditary multiple fibrofolliculomas with trichodiscomas and acro- chordons. Arch Dermatol $1977 ; 113: 1674$ 1677

2) Collins GL, Somach S, Morgan MB : Histomorphologic and immunophenotypic analysis of fibrofolliculomas and trichodiscomas in BirtHogg-Dube syndrome and sporadic disease. J Cutan Pathol $2002 ; 29: 529-533$

3) Zbar B, Alvord WG, Glenn G, et al : Risk of renal and colonic neoplasms and spontaneous pneumothorax in the Birt-Hogg-Dube syndrome. Cancer Epidemiol Biomarkers Prev 2002; 11 : $393-400$

4) Toro JR, Pautler SE, Stewart L, et al : Lung cysts, spontaneous pneumothorax, and genetic associations in 89 families with Birt-Hogg-Dube syndrome. Am J Respire Crit Care Med 2007; $175: 1044-1053$

5) Gunji $Y$, Akiyoshi T, Sato T, et al : Mutations of the Birt Hogg Dube gene in patients with multiple lung cysts and recurrent pneumothorax. J Med Genet $2007 ; 44: 588-593$

6) Schmidt LS, Nickerson ML, Warren MB, et al : Germline BHD-mutation spectrum and phenotype analysis of a large cohort of families with Birt-Hogg-Dube syndrome. Am J Hum Genet $2005 ; 76: 1023-1033$

7) Toro JR, Glenn G, Duray P, et al : Birt-HoggDube syndrome : a novel marker of kidney neoplasia. Arch Dermatol $1999 ; 135: 1195-1202$

8）矢尾正祐, 中井川昇, 槙山和秀他：遺伝性腎がん 症候群の遺伝子診断と診療の現状．泌外 2015 ； $28: 611-612$

\title{
A CASE OF BIRT-HOGG-DUBE SYNDROME WITH RECURRENT PNEUMOTHORAX
}

\author{
Kana NAGAYAMA, Kana KITAHARA, Rei KOBAYASHI, \\ Yasuhiro TAKAHASHI and Ryoji KAWANO \\ Department of Respiratory Surgery, Itabashi Chuo Medical Center
}

The case involved a 35-year-old woman who underwent surgery for left spontaneous pneumothorax at another hospital 6 years previously and thereafter experienced recurrences twice which were conservatively treated. Recently she felt right chest pain when she got up and visited a neighboring hospital. She was referred to our hospital with a diagnosis of second-degree right pneumothorax. A chest CT scan revealed multiple lung cysts in the right middle lower lobe. A patient interview revealed that her mother also had a history of pneumothorax. Hereditary pulmonary cystic disease was likely. Since she had developed metachronous bilateral pneumothoraxes, we decided to indicate surgery. We performed video-assisted thoracoscopic removal of the lung cysts. The postoperative course was uneventful and she was discharged from our hospital on the $5^{\text {th }}$ postoperative day. A genetic analysis performed after discharge revealed mutation of exon 12 in the FLCN gene that was compatible with Birt-Hogg-Dube (BHD) syndrome.

Since BHD syndrome is a rare entity, has a variety of expressions, and requires the genetic analysis to make the definite diagnosis, the diagnosis of the syndrome is difficult. This paper deals with a case of BHD syndrome presented with recurrent pneumothorax.

Key words : BHD syndrome, pneumothorax, lung cyst 